Version Date: 7/14/97

ICNS '97 Proceedings Paper to be published in Physica B- Condensed Matter

\title{
Spectroscopic Study of the Proton Dynamics in Manganese Dioxide Electrode Materials
}

\author{
C. S. Johnson a, M. M. Thackeray ${ }^{a}$, J. C. Nipko ${ }^{b}$, and C.-K. Loong \\ Argonne National Laboratory, Argonne, IL 60439, U.S.A. \\ ${ }^{2}$ Electrochemical Technology Program, Chemical Technology Division ${ }^{2} \mathrm{I}$ \\ ${ }^{b}$ Intense Pulsed Neutron Source Division \\ AUG 261997 \\ OST!
}

Abstract

$\vdots \quad \vdots$

Proton or lithium diffusion is a critical electrode process that occurs in manganese dioxide electrode materials during cycling of either aqueous (alkaline) or non-aqueous (lithium) batteries. The structural and electrochemical properties of a number of hydrated alpha-phase manganese dioxide compounds $\left(\alpha-\mathrm{MnO}_{2} \bullet \mathrm{nH}_{2} \mathrm{O} ; \mathrm{n} \approx 0.2-0.33\right)$, the heattreated products $(n=0-0.1)$, as well as their more stable lithia-doped derivatives, $\alpha$ $\left[\mathrm{xLi}_{2} \mathrm{O}\right] \bullet \mathrm{MnO}_{2}(0 \leq \mathrm{x} \leq 0.25)$, have been investigated. Inelastic neutron scattering was used as a means to differentiate and interrogate the key proton or water interactions in these $\mathrm{MnO}_{2}$ structures. The neutron spectra reveal excitations associated with the hydrogen vibrations centered at $4,13,16,26,36,65,90,110,140,200,420$, and 490 $\mathrm{meV}$ in the alpha-phase and $14,24,65,84,100,202$, and $425 \mathrm{meV}$ in the lithia-doped derivatives. Band assignments were carried out by comparing these frequencies with those reported for structurally similar hydrated $\gamma-\mathrm{MnO}_{2}$ compounds and by comparison with infrared data.

Keywords: manganese dioxide, lithium battery, neutron scattering

Correspondence:

Dr. Christopher S. Johnson

CMT, Building 205

Argonne National Laboratory

Argonne, IL 60439-4814
FAX: $\quad(630) 252-4167$

Email: johnsoncs@cmt.anl.gov

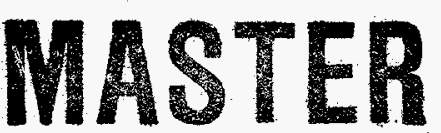




\section{DISCLAIMER}

This report was prepared as an account of work sponsored by an agency of the United States Government. Neither the United States Government nor any agency thereof, nor any of their employees, makes any warranty, express or implied, or assumes any legal liability or responsibility for the accuracy, completeness, or usefulness of any information, apparatus, product, or process disclosed, or represents that its use would not infringe privately owned rights. Reference herein to any specific commercial product, process, or service by trade name, trademark, manufacturer, or otherwise does not necessarily constitute or imply its endorsement, recommendation, or favoring by the United States Government or any agency thereof. The views and opinions of authors expressed herein do not necessarily state or reflect those of the United States Government or any agency thereof. 


\section{DISCLAMIER}

Portions of this document may be illegible in electronic image products. Images are produced from the best available original docomenent 


\section{Introduction}

Manganese dioxide $\left(\mathrm{MnO}_{2}\right)$ materials are increasingly being chosen as the active electrode material in non-aqueous, primary lithium ( $\mathrm{L} /$ non-aqueous organic electrolyte/ $\left(\mathrm{MnO}_{2}\right)$, and secondary (rechargeable) lithium-ion batteries $\left(\mathrm{Li}_{\mathrm{x}} \mathrm{C}_{6} /\right.$ non-aqueous organic electrolyte/ $/ i_{1-x} M_{2} \mathrm{O}_{4}$ ) [1]. $\mathrm{MnO}_{2}$ is attractive because of its relatively low cost compared to either nickel in $\mathrm{Ni}-\mathrm{MH}$ (metal-hydride) or cobalt in lithium-ion $\left(\mathrm{LiCoO}_{2}\right)$ secondary batteries. Moreover, recent data has demonstrated good performance from $\mathrm{MnO}_{2}$-based chemistries as well, with cells exhibiting high energy/power density properties [2].

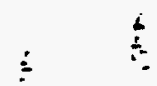

The development of non-aqueous $\mathrm{MnO}_{2}$ cells has evolved as a result of the use of $\gamma$ $\mathrm{MnO}_{2}$ initially as a primary cathode in aqueous alkaline batteries $\left(\mathrm{Zn} / \mathrm{KOH} / \mathrm{MnO}_{2}\right)$. In the aqueous cell, the discharge process is governed by the diffusion and reaction of protons $\left(\mathrm{H}^{+}\right)$on the surface of the $\gamma-\mathrm{MnO}_{2}$ electrode particle. Due to the chemical similarity of $\mathrm{Li}^{+}$ to $\mathrm{H}^{+}$, it is reasonable to expect that the behavior of the lithium cation in a non-aqueous cell may be equivalent. In fact, specially heat-treated $\gamma-\mathrm{MnO}_{2}$ functions quite well, giving 3 volts in a lithium non-aqueous cell and yielding capacities in the range of $200 \mathrm{mAh} / \mathrm{g}$, equivalent to the insertion of about $0.65 \mathrm{Li}$ per mole of $\mathrm{MnO}_{2}$ [3] However, these particular materials have limited reversibility which hinders their rechargeability.

Our studies have focused on the preparation and characterization of a class of new alpha-phase $\left(\alpha-\mathrm{MnO}_{2}\right)$ materials which possess good rechargeability in terms of capacity and rate in $3 \mathrm{~V}$ lithium cells. The objective is to obtain information about the role hydrogen plays in $\mathrm{H}$-bonding and diffusion in these materials. In turn, data from inelastic neutron scattering studies may help us formulate a good comparison between hydrogen and lithium and allow us a better understanding of lithium $/ \mathrm{MnO}_{2}$ batteries. Due to the adverse reaction with metallic lithium or a lithiated negative electrode, the minimization of water in a non-aqueous lithium cell is necessary for its proper operation. 


\section{Experimental}

Hydrated alpha manganese dioxide $\left(\alpha-\mathrm{MnO}_{2} \bullet \mathrm{H}_{2} \mathrm{O} ; \mathrm{n} \approx 0.2-0.33\right)$, its heat-treated product and the subsequent lithium-oxide stabilized product $\left(\alpha-\left[x L i_{2} \mathrm{O}\right] \$ \mathrm{MnO}_{2}\right)$ were synthesized as previously described [4]. A detailed description of the electrochemical experiments may be found in reference 4 .

Inelastic neutron scattering experiments on two hydrated samples ( $\alpha$ $\left.\mathrm{MnO}_{2} \bullet 0.25 \mathrm{H}_{2} \mathrm{O}, \alpha-\mathrm{MnO}_{2} \bullet 0.33 \mathrm{H}_{2} \mathrm{O}\right)$, a dehydrated $\left(\alpha-\mathrm{MnO}_{2}\right)$ and partially dehydrated product $\left(\alpha-\mathrm{MnO}_{2} \bullet 0.10 \mathrm{H}_{2} \mathrm{O}\right)$, a subsequent lithium-oxide stabilized $\left(\alpha-\left[0.143 \mathrm{Li}_{2} \mathrm{O}\right]\right.$ - $\left.\mathrm{MnO}_{2}\right)$ product, and a similar deuterated sample $\left(\alpha-\mathrm{MnO}_{2} \bullet 0.12 \mathrm{D}_{2} \mathrm{O}\right)$, were carried out using the HRMECS spectrometer at IPNS. Incident energies of 50,150,170, 250, 350, and $600 \mathrm{meV}$ were chosen and the sample temperature was controlled in a range of 6-15 $\mathrm{K}$.

\section{Results}

Alpha- $\mathrm{MnO}_{2}$ has a framework structure containing $\mathrm{MnO}_{6}$ octahedra. It has been commonly believed that the $\alpha-\mathrm{MnO}_{2}$ structure is stabilized by a foreign cation such as $\mathrm{K}^{+}, \mathrm{NH}_{4}^{+}$, or $\mathrm{Ba}^{2+}$ within the $2 \times 2$ tunnel interstitial space of the framework [5]. From our synthesis method, we have succeeded to synthesize an $\alpha-\mathrm{MnO}_{2}$ structure devoid of such "stabilizing" cations [6]. The process yields a product which is highly crystalline and dense and which has a tetragonal symmetry $(\mathrm{I} 4 / \mathrm{m})$. The average unit cell parameters, determined from powder X-ray diffraction on 10 separate hydrated samples, are $a=b=9.813 \AA$ and $c=2.850 \AA$. Analyses of neutron diffraction data by Rietveld profile refinement have shown unequivocally that molecular water $\left(\mathrm{H}_{2} \mathrm{O}\right.$, or possibly $\mathrm{H}_{3} \mathrm{O}^{+}$) is present within the $2 \times 2$ tunnels of the structure and the oxygen atom of the water is located at the center of the tunnel in the $(0.0,0.0,0.5)$ unit cell position [4].

The hydrated $\alpha-\mathrm{MnO}_{2}$ can be heat-treated at $275{ }^{\circ} \mathrm{C}$ in air to remove surface-bound water and water within the $2 \times 2$ tunnels. Thermogravimetric data collected on this material showed that about $4-5$ wt.- $\%$ water was present as structural $(2 \times 2)$ tunnel water, 
and 2-3 wt.-\% was present as surface (interfacial) water. Furthermore, the $\alpha-\mathrm{MnO}_{2}$ structure itself remains intact at temperatures up to $400^{\circ} \mathrm{C}$. Structure analysis of the heattreated samples confirmed earlier reports that the $\mathrm{MnO}_{2}$ framework structure remains intact during dehydration [7] and showed that, on average, the unit cell contracts by about $0.5 \%$ $(\mathrm{a}=\mathrm{b}=9.763 \AA, c=2.860 \AA)$.

The $\alpha-\mathrm{MnO}_{2}$ framework structure can be stabilized by an exchange of the $\mathrm{H}_{2} \mathrm{O}$ component in the $\alpha-\mathrm{MnO}_{2} \bullet \mathrm{nH}_{2} \mathrm{O}$ hydrated phase with $\mathrm{Li}_{2} \mathrm{O}$, and that $\mathrm{n}$ can reach a value of 0.15 (in $\mathrm{nLi}_{2} \mathrm{O}$ ) without structural degradation of the $\alpha-\mathrm{MnO}_{2}$ framework [4]. The unit cell parameters of several samples with varying Li:Mn mole ratios were calculated from powder $\mathrm{X}$-ray diffraction data. The unit cell expands, almost linearly, with increasing lithium content to a $\mathrm{Li}: \mathrm{Mn}$ ratio of $0.3: 1$ without the appearance of a second phase; with this ratio the unit cell parameters are $a=b=9.932 \AA$, and $c=2.852 \AA$. Chemical analysis of lithium-oxide doped products quantitatively verified the reactant $\mathrm{Li}: \mathrm{Mn}$ mole ratio. The $\mathrm{O}^{2-}$ anions occupy crystallographic positions within the $2 \times 2$ tunnels (Fig. 1); the lithium cations appear to be coordinated octahedrally to the oxygen atoms of the framework structure and those located within the $2 \times 2$ tunnels [4].

Interactions between the $\mathrm{H}_{2} \mathrm{O}$ molecules with the $\mathrm{MnO}_{2}$ structure are important to address because of their structural equivalency to the $\mathrm{Li}_{2} \mathrm{O}$ molecule. These were assessed by inelastic neutron scattering measurements. The inelastic neutron cross-section scattering coefficient of hydrogen is at least one order of magnitude greater than that of manganese or oxygen. Thus, the intensities of bands in the energy transfer spectra are predominantly due to hydrogen interactions within the structure. Fig. 2 shows a representative, baseline-corrected spectrum of $\alpha-\mathrm{MnO}_{2} \bullet 0.25 \mathrm{H}_{2} \mathrm{O}$ obtained with a neutron incident energy of $600 \mathrm{meV}$. Fig. 2 also displays the spectrum of the same sample after heat treatment at $275^{\circ} \mathrm{C}$. This spectrum is essentially featureless in terms of hydrogen interactions and confirms that water is removed from $\alpha-\mathrm{MnO}_{2}$ on heat treatment. Note that the presence of a large continuum background in the spectrum of the hydrated sample 
suggests significant mobility of hydrogen ions. This spectra are similar to a previously reported neutron scattering survey of other manganese oxide structures which have been used in rechargeable lithium batteries [8]. A detailed analysis of the neutron results in conjunction with the electrochemical properties of the $\mathrm{Li}$-inserted $\mathrm{MnO}_{2}$ system will be given elsewhere.

\section{Acknowledgments}

We gratefully acknowledge support for this work from the U. S. Department of Energy's Advanced Battery Research Program, Chemical Sciences Division, Office of Basic Energy Science. Work performed at Argonne is sthpported by the U.S.DOE-BES under Contact No.W-31-109-ENG-38.

\section{References}

[1] M. M. Thackeray, M. H. Rossouw, A. de Kock, A. P. de la Harpe, R. J. Gummow, K. Pearce, and D. C. Liles, J. Power Sources, $43-44$ (1993), 289.

[2] G. Pistoia, and A. Antonini, J. Electrochem. Soc., 144 (1997) 1553.

[3] T. Nohma, Y. Yamamoto, I. Nakane, and N. Furakawa, J. Power Sources, 39 (1992) 51 .

[4] C. S. Johnson, D. W. Dees, M. F. Mansuetto, M. M. Thackeray, D. R. Vissers, D. Argyriou, C.-K. Loong, and L. Christensen, J. Power Sources, in press (1997).

[5] A. F. Wells, Structural Inorganic Chemistry ( $4^{\text {th }}$ edition), 458 (1975), Clarendon Press, Oxford, UK.

[6] M.H. Rossouw, D.C. Liles, and M.M. Thackeray, Prog. Batt. and Batt. Mat. 15 (1996) 8 .

[7] M.H. Rossouw, D.C. Liles, M. M. Thackeray, W.I.F. David, and S. Hull, Mat. Res. Bull. 27 (1992) 221.

[8] C. Cachet, A. Belushkin, I. Natkaniec, A. Lecerf, F. Fillaux, and L. T. Yu, Physica B 213/214 (1995) 827. 
Figure Caption:

Fig. 1 The positions of the oxygen atoms within the $2 \times 2$ tunnels of the lithiated $\alpha-\mathrm{MnO}_{2}$ structure.

Fig. 2 Representative base-line corrected inelastic neutron scattering spectra for $\alpha$ $\mathrm{MnO}_{2} \bullet 0.25 \mathrm{H}_{2} \mathrm{O}$ (open circles) and the same sample after heat treatment at $275{ }^{\circ} \mathrm{C}$ (filled circles). 


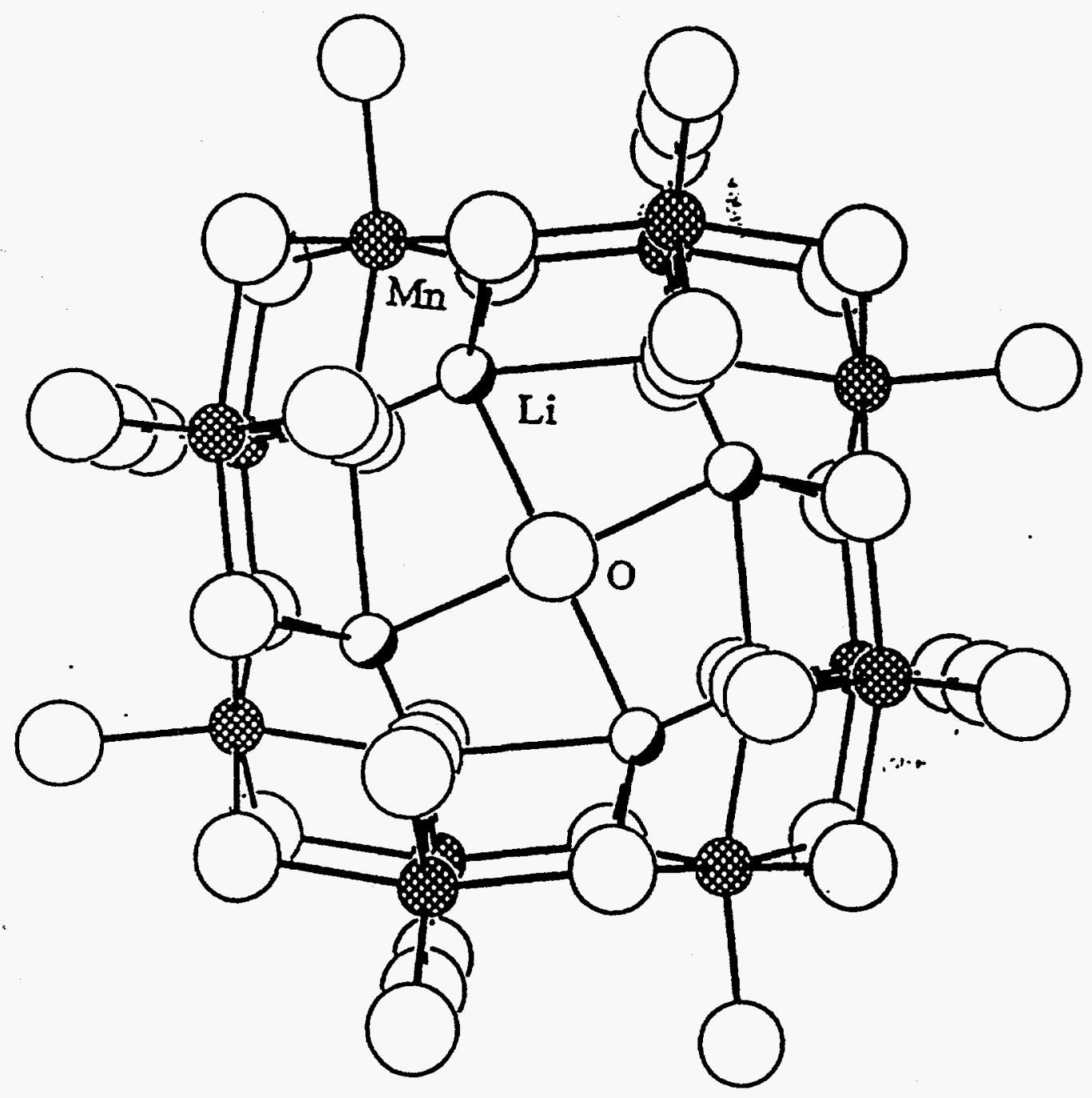

Fig. 1 "Spectroscopic Study of ... " C. S. Johnson et. al. 


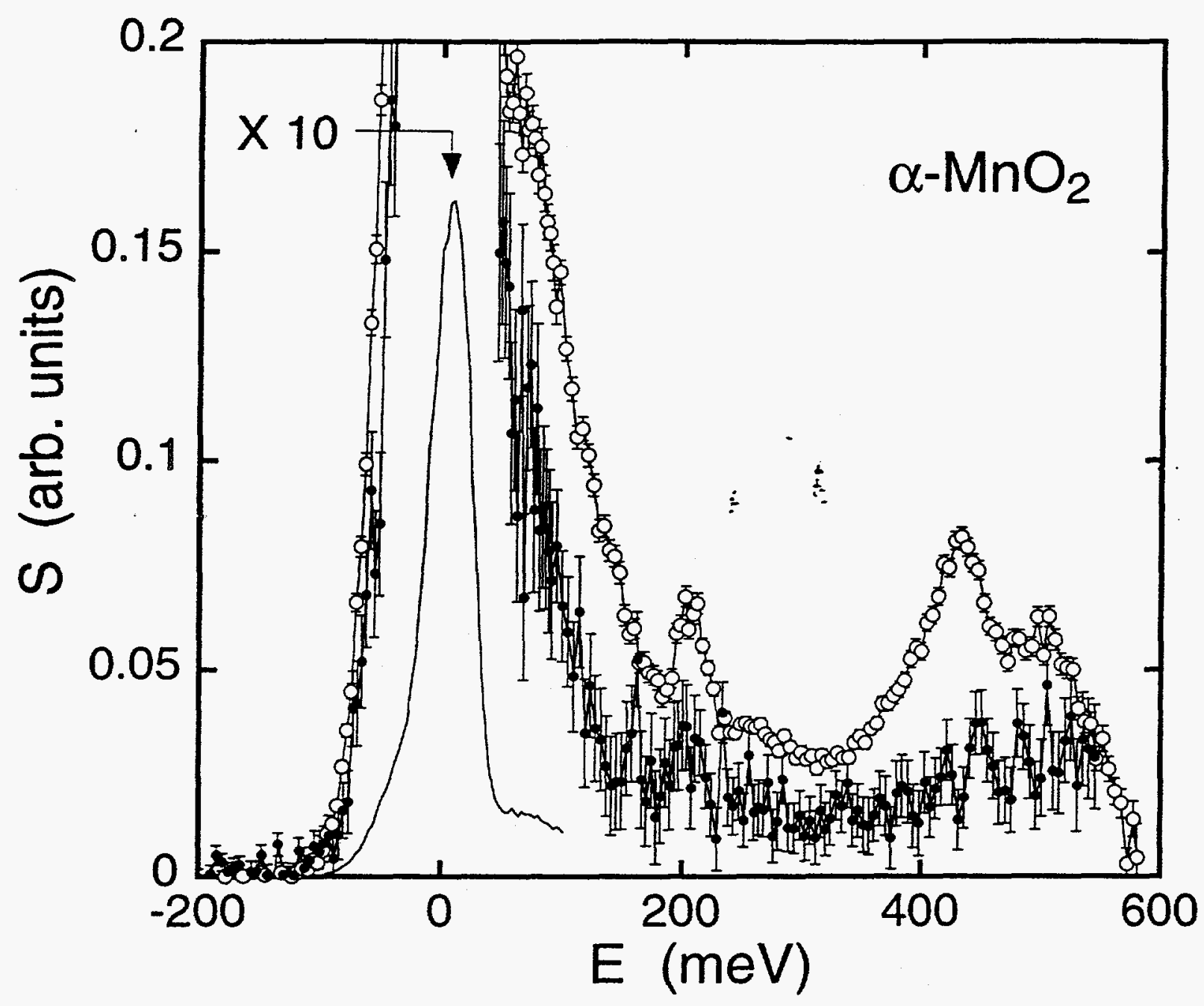

Fig. 2: "Spectroscopic Study of ... " C. S. Johnson et. al. 